\title{
Can Human Resource Practice and Job Characteristics Increase Employee Engagement and Organizational Commitment? Empirical Study from a Coal Mining Company in Indonesia
}

\author{
Muhammad Baiquni and Ayu Aprilianti Lizar \\ Universitas Indonesia, Depok, Indonesia
}

Correspondence should be addressed to: Muhammad Baiquni; baiquni.8@gmail.com

Received date:6 December 2019; Accepted date: 16 October 2020; Published date: 29 December 2020

Copyright (C) 2020. Muhammad Baiquni and Ayu Aprilianti Lizar. Distributed under Creative Commons Attribution 4.0 International CC-BY 4.0

\begin{abstract}
This study examined the role of human resource practice and job characteristics on employee engagement and organizational commitment, and also examined the role of employee engagement as the mediator on the relationship between human resource practice, job characteristics and organizational commitment. Previous studies found that HR practice and job characteristics play significant role in increasing employee engagement and organizational commitment. However, the process of how HR practice and job characteristics influence organizational commitment trough employee engagement is rarely discussed yet, especially in the context of Indonesia. Data from 213 respondents were collected through questionnaires and analyzed using structural equational modeling. The result showed that HR practice and job characteristics positively influence organizational commitment, while job characteristics positively influence organizational commitment, and employee engagement positively influence organizational commitment. However, surprisingly the result of this study also showed that HR practice negatively influence employee engagement. This study revealed different result with the majority of the studies that found HR practice has positive influence on employee engagement. Regarding this surprising result we conclude that HR practice can be considered as "best practice" that can differ for each company and can produce different results in their implementation for each company or organization. Therefore, the context in which this practice is implemented play significant role in determining the result.
\end{abstract}

Keywords: Human Resource Practice, Employee Engagement, Job Characteristics, Organizational Commitment

\section{Introduction}

Management theories that exist at either the micro or the macro level predict that investments in human resource (HR) management can improve corporate performance (Crook et al., 2011). These theories imply that HRs are important elements in influencing the course of an organization. Currently, humans are often viewed as assets of an organization. Thus, investments in HRs create positive effects on both individual and organizational performance (Crook et al., 2011). However, to create and sustain above-average organizational performance, having competent

Cite this Article as: Muhammad Baiquni and Ayu Aprilianti Lizar (2020)," Can Human Resource Practice and Job Characteristics Increase Employee Engagement and Organizational Commitment? Empirical Study from a Coal Mining Company in Indonesia", Journal of Human Resources Management Research, Vol. 2020 (2020), Article ID 393044, DOI: $10.5171 / 2020.393044$ 
HRs (employees) is not enough. These employees also need to be committed. Therefore, the company must be able to design strategic HR systems and practices that can develop employees' competencies and commitment, especially in an era of turbulence, economic downturns, and intense competition. Despite the difficulties that a company may encounter, strategic HR management practices that start from planning, development, and retaining employees should be implemented.

The coal mining industry in Indonesia has faced a difficult situation during the last two years. Global coal price trends are expected to remain low given falling commodity prices and demand. This situation has posed challenges for the development of Indonesia's coal sector (DBS Group Research, 2017). However, most economic experts predict that the domestic industry can survive if it keeps production costs low. This situation requires companies to design effective strategies to maintain and even increase employee commitment. Committed employees remain loyal to the company despite its difficulties (Meyer et al., 2002). Moreover, Meyer et al. (2002) illustrated that organizational commitment, specifically affective commitment, is strongly related to employee performance within the organization.

Organizational commitment can be defined generally as a psychological attachment between employees and their organization that makes employees less likely to leave the organization (Allen and Meyer, 1996). Organizational commitment is defined as "the relative strength of an individual's identification with and involvement in a particular organization and can be characterized by a strong belief in and acceptance of the organization's goals and values, willingness to exert considerable effort on behalf of the organization and a strong desire to maintain membership of the organization" (Mowday, Porter, and Steers, 1983).

Other than organizational commitment, employee engagement is also considered as an important aspect that relates to employee performance. Saks (2006) stated that employee engagement can positively influence employee commitment. Employee engagement has no single definition or measure. The various definitions form the basis on which to construct other concepts, such as organizational commitment and organizational citizenship behavior (Robinson, Perryman, and Hayday, 2004). Frank, Finnegan, and Taylor
(2004) stated that employee engagement is generally defined as the discretionary effort shown by employees in their jobs. Employee engagement can also be described as individual involvement and satisfaction and an enthusiasm for work (Harter, Schmidt, and Hayes, 2002).

According to Saks (2006), employee engagement can be influenced by job characteristics. Diverse job characteristics allow an individual to develop and use all of his or her abilities to get the job done. Job characteristics can also encourage or enhance the productivity and quality of the work experience (Hackman and Oldham, 1976). Redesigning work is becoming more prominent as a strategy to improve the productivity and quality of employees' work experiences (Hackman and Oldham, 1976). Rai et al. (2017) found a positive relationship between job characteristics and employee engagement, but this relationship was moderated by other factors.

Moreover, Ulrich (1997) stated that HR practices can be considered as an effective tool in enhancing organizational commitment (Ulrich, 1997). Strategic HR practices can be defined as activities for managing employees that are theoretically or empirically related to an organization's overall performance, and seven practices are consistently considered to be strategic HR practices (Delery and Doty 1996). HR practices can assist companies in shaping employees' attitudes and behavior, in turn leading to improved staff performance (Koch and Mcgrath, 1996).

Training, employee participation, results-oriented assessments, and internal career opportunities as part of HR practices can influence performance in the form of both products or services and financial performance (Akhtar, Ding, and GE, 2008). In addition, Paul and Anantharaman (2004) stated that HR practices have a significant positive relationship with organizational commitment, whereas Lamba and Choudhary (2013) found that compensation, training, development, and employee participation play important roles in increasing organizational commitment in the banking sector. In the academic sector, the HR practice found to significant affect organizational commitment is career development. However, the same HR policy that is effective in one organization might not produce the same results in other organizations. Meyer and Smith (2000) concluded that a relationship exists between HR practices and organizational commitment that can be mediated by certain factors. 
To our knowledge, limited research had been conducted to examine the mediating role of employee engagement in the relationship between HR practices, job characteristics, and organizational commitment. Furthermore, most of the research that investigates the relationship between HR practices and job characteristics with positive attitudinal outcomes, such as engagement and organizational commitment, was conducted in the western context. Meanwhile, similar research in Indonesia context remains limited. As an Asian country, Indonesia has different cultural and economic context with most western countries. According to Hofstede's cultural values, Indonesia is considered to have high power distance, be more collective in nature, and have a high context culture. (Hofstede, 2005). Given this difference and the turbulence and challenging economic conditions surrounding the coal mining industry in Indonesia, we conducted this research to investigate the relationship between HR practices and job characteristics with organizational commitment in a coal mining company in Indonesia as mediated by employee engagement.

\section{Analytical Framework}

\section{Organizational Commitment}

Organizational commitment can be defined as the relative strength of an individual's identification with and involvement in a particular organization, and is characterized by a strong belief in and acceptance of the organization's goals and values, willingness to exert considerable effort on behalf of the organization, and a strong desire to stay with the organization (Mowday, Porter and Steers, 1983). Organizational commitment is important because it addresses how employees work and survive in an organization (Meyer et al., 2002). Organizational commitment is described by Allen and Meyer (1990) as the psychological engagement felt by an individual for the organization that influences the extent to which the individual internalizes or adopts organizational characteristics or perspectives. Organizational commitment can also be defined as the normative pressure to behave in a manner that meets the organization's goals and desires (Wiener, 1982).

Allen and Meyer (1996) classified organizational commitment into three categories. The first category is affective commitment, defined as the condition in which employees have positive thoughts about their work and feel comfortable and competent. Second category is continuance commitment that refers to a condition in which employees feel a commitment to the organization because they perceive the various costs that may be incurred when leaving the organization. The third category is normative commitment which is defined as the obligation to stay with an organization because it is the right thing to do. Employees with strong affective commitment remain with an organization because they want to, whereas employees with a strong continuance commitment remain because they need to, and those with a strong normative commitment remain because they believe they should.

Organizational commitment is a significant aspect of an employee's psychological condition. Theoretically, employees who experience high organizational commitment display more positive behavior at work than employees who experience low organizational commitment.

\section{Employee Engagement}

Employee engagement is a form of work identity in which employees believe in what they do and identify themselves with their work; therefore, they have more to contribute to the success of their organization (Kahn, 1990). Employee engagement can also be described as a desirable condition in which an employee has an organizational purpose and connotes involvement, commitment, passion, enthusiasm, focused effort, and energy. Employee engagement has both attitudinal and behavioral components (Macey and Schneider, 2008). Bakker and Demerouti (2008) described the concept of engagement as a high level of energy and strong identification with one's work. The literature provides ample evidence of various outcomes of employee engagement in service industries. For example, in a study on 196 pairs of employeecustomer respondents in healthcare organizations, Lee, Lee, and Kang (2012) found that employee engagement is one measure by which hospitals can improve customer satisfaction and loyalty.

The term employee engagement is commonly used in both the academic and business literature (Buckingham and Coffman, 1999, in Lee, Whittington and Galpin, 2010). Employee engagement has a positive relationship with productivity, profitability, employee retention, safety, and customer satisfaction. Employee engagement refers to the individual's involvement in and satisfaction with, as well as enthusiasm for, work (Harter, Schmidt and Hayes, 2002). In addition, Saks (2006) defined employee 
engagement as the extent to which an individual is attentive to and absorbed with performing his/her roles.

Engagement is defined as a positive attitude, full of meaning and motivation, and is divided into three aspects: vigor, dedication, and absorption. Vigor is characterized by high energy levels, resilience, a desire to strive, and not giving up in the face of challenges. Dedication is characterized by feelings of worth, enthusiasm, inspiration, value, and challenge. Absorption is characterized by full concentration on a task (Schaufeli, Bakker, and Salanova, 2006).

\section{HR Practice}

HR practices cover all aspects of how a person is employed and managed by an organization (Armstrong, 2014). Ogilvie (1986) described HR management practices as concrete, tangible programs designed to develop commitment. Many studies on HR practices have been conducted from time to time, and researchers have identified different practices with different names (Tiwari and Saxena, 2012). HR practices directly or indirectly affect several other variables in the organization. Initially, Pfeffer (1994) identified 16 practices denoted as a best practice, a list that was subsequently refined to the following seven practices: employment security; selective hiring; self-managed teams/teamwork; high compensation; contingent on organizational performance; extensive training and reduction in status differences; and sharing information. Robbins and Judge (2012) explained HR practices as all activities of HR management that include recruitment, development, and maintenance. These activities need to be managed effectively to aid the organization in achieving its goals. HR practices have been regarded as an effective tool for enhancing organizational commitment (Ulrich, 1997, in Paul and Anantharaman, 2004).

According to Delery and Doty (1996), strategic HRs are theoretically or empirically related to overall organization performance. Delery and Doty (1996) also identified seven practices that are consistently considered strategic HR practices: internal career opportunities, formal training systems, appraisal measures, profit sharing, employment security, participation, and job definition. The practice of HRs is also a control approach that aims to increase efficiency and reduce direct labor costs and relies on strict work rules, procedures, and base rewards for outputs (Arthur, 1994). This practice also includes rules, sanctions, rewards, and monitoring to shape employee behavior (Wood and De Menezes, 1998).

\section{Job Characteristics}

Focusing on job characteristics is an approach that emphasizes the importance of an alignment between the character of a job and the character of the employee (Kulik, Oldham, and Hackman, 1987). The job characteristics theory provides five core characteristics of any job that contribute to personal and job-related outcomes for the three psychological states of meaningfulness, experienced responsibility, and knowledge of results (Hackman and Oldham, 1976). The job characteristics model from Hackman and Oldham (1976) has five dimensions: skill variety or the degree to which a job requires a variety of different activities to carry out the work; task identity or the degree to which a job requires completion of a "whole" and identifiable piece of work, that is, doing a job from beginning to end with a visible outcome; task significance or the degree to which the job has a substantial impact on the lives or work of other people, whether in the immediate organization or the external environment; autonomy, which is the degree to which the job provides substantial freedom, independence, and discretion to the individual through work scheduling and when determining the procedures to be used in carrying out the work; and, finally, feedback or the degree to which carrying out work activities required by the job results in the individual obtaining direct and clear information about the effectiveness of his or her performance.

The job characteristics model suggests that individuals' aspects shape their perceptions of jobs (Hackman and Oldham, 1976). These aspects include the jobholder's internal motivation at work, satisfaction with both the job in general and opportunities for personal growth and development offered by the job, and the production of high-quality work.

\section{Research Model}

The model for this research was drawn from Saks (2006) on the antecedents and consequences of employee engagement, Fiorito et al. (2007) and Albdour and Altarawneh (2014) on the relationship between organizational commitment and employee engagement. Regarding the effects of employee engagement on organizational commitment, Schaufeli and Salanova (2007) studied work engagement and found that when engagement increases, the level of organizational 
commitment increases as well. This commitment increase also enhances job satisfaction and performance and reveals a greater demonstration of personal ideas, higher attendance and lower turnover rates, improved health and security, proactive behavior, and learning motivation.

Meyer and Smith (2009) showed through their research that HR practices can affect organizational commitment and, more specifically, affective commitment. This result is in line with other research that found that HR practices have been considered to be effective tools for enhancing organizational commitment (Ulrich, 1997). In addition, Saks (2006) also found that employee engagement mediates the relationship between antecedent variables and consequences. One of the antecedents was job characteristics, and the consequences was organizational commitment. The result showed that the job characteristics factor positively affects the organizational commitment mediated by employee engagement.

Meaningful work can be achieved from challenging job characteristics, including jobs that require different types of skills and opportunities to contribute more to the organization. The explanation corresponds to the characteristic model of work expressed by Hackman and Oldham (1976). Job characteristics are comprised of five dimensions: skill variety, task identity, task significance, autonomy, and feedback. An employee that does work that has these five characteristics can make him or her feel that what he or she is doing is meaningful, and he or she subsequently develops a sense of engagement. Saks (2006) found that the job characteristics factor has a significant influence on employee engagement. Based on that argument, the first hypothesis in this research is as follows.

H1: Job characteristics can have a significant positive influence on employee engagement.

HR practices have several dimensions, including recruitment and selection, training, payroll, and performance appraisal. Fulfillment of employees' basic needs is a purpose of HR practices. Once the company meets employees' basic needs, employees can focus on their work, which also increases employee engagement (Dessler, Cole, and Sutherland, 2017). Based on that argument, the second hypothesis is as follows.

H2: HR practices have a significant positive influence on employee engagement.
Saks (2006) found that several factors can influence employee engagement, and employee engagement can influence other positive attitudinal outcomes that include organizational commitment. This result is supported by Albdour and Altarawneh (2014), who showed the relationship between employee engagement and organizational commitment. Therefore, the third hypothesis is as follows.

H3: Employee engagement has a significant positive influence on organizational commitment.

Mowday (1982, in Allen and Meyer, 1990) found that one factor that influences organizational commitment is job characteristics. This statement was supported by Meyer et al (2002) as well. Therefore, the fourth hypothesis of this research is as follows.

H4: The job characteristics factor has a significant positive influence on organizational commitment.

HR practices can influence how employees perceive their work and the organization. HR practices also play a role in keeping an employee committed to the organization. Training that can enhance competences, ease career advancement, and ensure fair compensation can fulfill some employees' basic needs and provide a sense of satisfaction. Therefore, committed HR practices can increase employees' organizational commitment (Saks, 2006). Then, we develop the fifth hypothesis as follows.

H5: HR practices have a significant positive influence on organizational commitment.

According to Baron and Kenny (1986, in Saks, 2006), three conditions must be met to form a mediation. First, the independent variable should be linked to the mediator. Second, the mediator must also be related to the dependent variable. Third, the significant relationship between the variables and the dependent variable is reduced or no longer significant when associated with the mediator. Maslach et al. (2001, in Saks, 2006) used a model to explain that variables such as job characteristics, perceived organizational support, and organizational justice perceptions are related to certain work outcomes. Furthermore, some studies such as those conducted by Schaufeli and Bakker (2004, in Saks, 2006) suggested that employee engagement mediates the relationship between antecedents and outputs. Furthermore, Saks (2006) found that employee engagement

Muhammad Baiquni and Ayu Aprilianti Lizar, Journal of Human Resources Management Research, DOI: $10.5171 / 2020.393044$ 
plays a role as a mediator in the relationship between job characteristics and organizational commitment. Therefore, the sixth hypothesis of this research is as follows.

H6: The job characteristics factor has a significant positive influence on organizational commitment as mediated by employee engagement.

Employee engagement is correlated with service productivity for customers, and increased employee engagement is significantly correlated with increased sales, product quality, productivity, retention, and revenue growth (Dessler, Cole and Sutherland, 2017). Dessler et al. (2017) also provided an example of how a troubled auto company can improve its business performance by applying HR practices aimed at enhancing employee engagement to improve employee morale and employee turnover. Based on this explanation, the seventh hypothesis of this research is as follows.

H7: HR practices have a significant positive influence on organizational commitment mediated by employee engagement.

\section{Method}

This research used quantitative method. The respondents for this research were employees who worked at a coal mining company in their current jobs for a minimum of one year. Data from 213 respondents were collected through a questionnaire.

The questionnaire included a cover letter/consent form that informed respondents about the purpose of the research. The respondents were asked to complete the survey for research on employee work experiences and attitudes. Participation was voluntary and respondents were informed that their responses would remain anonymous and confidential. The questionnaires used for each variable were adapted from several previous studies and were translated into Bahasa Indonesia. Employee engagement was measured using the Utrecht Work Engagement Scale consisting of 17 items developed by Schaufeli, Bakker, and Salanova (2006). The job characteristics questionnaire used the job diagnostic survey, which consists of 14 items developed by Hackman and Oldham (1976). The questionnaire to measure HR practices consists of 21 items developed by Delery and Doty (1996). The questionnaire to measure organizational commitment consists of
24 items from research developed by Allen and Meyer (1990). The hypotheses were tested using structural equation modeling (SEM).

\section{Results and Discussion}

First, this research conducted a pre-test to evaluate the questionnaire. The pre-test analysis tested the level of validity and reliability of the questionnaire using factor analysis and Cronbach's alpha. Second, a descriptive analysis was conducted to describe the demographic profile of the respondents and the descriptive data. Following through, validity and reliability tests were conducted once again using the measurement analysis of the Lisrel software program. SEM was used for the hypothesis testing. After pre-testing the questionnaire, the items used in the pre-test will also be used in the main testing because the item results for the validity and reliability testing showed that all questionnaire items were valid and reliable.

Then, the validity and reliability results from the main testing indicate that some of the questionnaire items were not valid and were deleted. Reliability testing at the main testing stage used composite reliability (CR) and variance extracted (VE). The results are reliable if the CR value is equal to or higher than 0.70 . Another way to evaluate reliability is through $\mathrm{VE}$, with a minimum acceptable value of greater than or equal to 0.50 . VE values less than 0.5 are acceptable provided that the $\mathrm{CR}$ value still exceeds 0.6 (Fornell and Larcker, 1981). After evaluating the questionnaire, this research also evaluated the goodness of fit from the research model. Using the root mean square error of approximation value, the result shows that the model is a good fit and the research can continue to the next stage.

Before engaging in the hypothesis analysis, this research conducts a descriptive analysis. A descriptive analysis can provide information about the respondents' demographics. Table 1 provides the descriptive statistics of the respondents. The descriptive statistics show that respondents' gender distribution is dominated by males at 76 percent and females at only 24 percent. In addition to gender, the descriptive statistics also show that respondents' ages range from younger than 39 years-indicating that the employees in this research were primarily generation Y (Gursoy, Maier, and Chi, 2008)-and their ages range from 39 to 55 years, or only 43 percent of the respondents. 
The descriptive analysis also showed that respondents' education is spread over four levels: high school, diploma, bachelor, and master. The descriptive statistics indicate that most of the employees are at the bachelor level of education, and some are at the diploma and high school levels. Regarding length of service, most of the respondents have been working for six to ten years.

Table 1: Descriptive statistics of respondents

\begin{tabular}{|l|l|c|c|}
\hline \multicolumn{2}{|l|}{} & Frequency & Percentage (\%) \\
\hline \multirow{4}{*}{ Gender } & Male & 162 & 76 \\
\cline { 2 - 4 } & Female & 51 & 24 \\
\hline \multirow{5}{*}{ Education } & Generation X (>38) & 93 & 43 \\
\cline { 2 - 4 } & Generation Millennial $(<38)$ & 120 & 57 \\
\hline \multirow{5}{*}{ Working Time } & High School & 15 & 7 \\
\cline { 2 - 4 } & Diploma & 45 & 21 \\
\cline { 2 - 4 } & Bachelor & 147 & 69 \\
\cline { 2 - 4 } & Master & 6 & 3 \\
\cline { 2 - 4 } & 1-5 Year & 104 & 38 \\
\cline { 2 - 4 } & 6-10 Year & 28 & 49 \\
\cline { 2 - 4 } & $11-15$ Year & 0 & 13 \\
\cline { 2 - 4 } & More than 15 Year & 0 \\
\hline
\end{tabular}

Source: Data process

This research then proceeded to the hypothesis analysis using t-values from the Lisrel software output. Table 2 shows the t-values for the relationships among the variables, considered significant if higher than 1.645. First, the relationship between the HR practices variable and the organizational commitment variable is significantly positive, with a t-value of 2.01 . In addition, the relationship between HR practices and employee engagement is significantly negative, with a t-value of -3.62 . The relationship between job characteristics and employee engagement is significantly positive, with a t-value of 9.08, and the relationship between job characteristics and organizational commitment is positive and significant, with a t-value of 6.27 . Then, the relationship between employee engagement and organizational commitment is significantly positive, with a t-value of 9.26. These results provide support for $\mathrm{H} 1, \mathrm{H} 3, \mathrm{H} 4$, and $\mathrm{H} 5$. However, for H2-HR practice has a significantly positive influence on employee engagement-is rejected because the results indicate a negative influence of HR practice on employee engagement.

Table 2: T-values from SEM analysis

\begin{tabular}{|cl|c|c|}
\hline \multicolumn{2}{|c|}{ Variable } & $\mathbf{3}$ & $\mathbf{4}$ \\
\hline 1. & HR Practice & -3.62 & 2.01 \\
\hline 2. & Job Characteristics & 9.08 & 6.27 \\
\hline 3. & Employee Engagement & - & 9.26 \\
\hline 4. & Organizational Commitment & - & - \\
\hline
\end{tabular}

Source: Data process

Then, according to Baron and Kenny (1986), three conditions must be met to establish mediation. First, the independent variable must be related to the mediator. Second, the mediator must be related to the dependent variable. Third, controlling for the mediator reduces or makes insignificant the

Muhammad Baiquni and Ayu Aprilianti Lizar, Journal of Human Resources Management Research, 
significant relationship between the independent variable and a dependent variable. Conditions one and two have been met as described previously.
For condition three, the antecedents must first be related to the consequences.

Table 3: Mediation analysis

\begin{tabular}{|c|c|c|}
\hline Relationship & Direct Effect & Indirect Effect \\
\hline $\begin{array}{l}\text { HR Practice to Organizational } \\
\text { Commitment }\end{array}$ & 0,12 & $-0,31$ \\
\hline $\begin{array}{l}\text { Job Characteristics to Organizational } \\
\text { Commitment }\end{array}$ & 0,28 & 0,88 \\
\hline
\end{tabular}

Source: Data process

Table 3 provides the calculated values for mediation. Following Baron and Keny (1986), to test the mediation of the existing hypothesis, we observe the direct and indirect values of the relationship. Based on the results of the previous SEM test, Hypothesis H7-employee engagement mediates the relationship between HR practices and organizational commitment-is rejected because mediating employee engagement must be a positive influence. However, Hypothesis 6 is accepted-employee engagement mediates the relationship between job characteristics and organizational commitment.

The results obtained from this research indicate that each industry, as well as the company, will have different characteristics. This situation indicates that results of the research can also differ from that of previous research. An analysis of HR practices with employee engagement shows that HR practices will significantly decrease employee engagement. This finding indicates that better HR practices will decrease employee engagement. In addition, according to Tiwari and Saxena (2012), HR practices are "best practices" that can differ for each company and can produce different results in their implementation for each company or organization. Significant negative relationships between HR practices and employee engagement can be used to create a new strategy for the existing field of work within the coal mining company.

The negative relationship between HR practice and employee engagement triggered the researcher to confirm this result with some of the respondents. Interviews with some of the respondents showed that the negative influence was potentially caused by their lack of trust in their company's HR practice and the incompatibility of the practice with their jobs. Despite the challenging economic conditions that the company needed to overcome when this research was conducted, it has been attempting to improve its HR practice. However, the respondents did not perceive these initiatives as effective, which decreased respondents' trust in the HR practice. Some respondents stated that they could request a training program-and were welcome to make that request-but realizing that request was always delayed by top management because they considered the costs. This condition could cause respondents to feel less engaged with their jobs even though they were still committed.

This research also found several factors that could affect organizational commitment and employee engagement. Job characteristics affect both employee engagement and organizational commitment, and employee engagement also affects organizational commitment. This research also supports the results from Saks (2006) that employee engagement influences organizational commitment. Companies can improve their job characteristics to help enhance organizational commitment and employee engagement. Saks (2006) also supported the relationship between job characteristics and employee engagement, which suggests that companies that create better HR practices will directly influence employee commitment, and HR practices that are not relevant to improving employee engagement and can result in a loss of employee engagement.

Companies should also consider the role of employee engagement as a mediator for the relationship between job characteristics and organizational commitment. The mediation result indicates that employee engagement mediates a positive relationship between job characteristics and organizational commitment. This result also supports Saks (2006), who showed the same result about employee engagement as a mediator. Organizational commitment within a coal mining company is influenced by job characteristics because the specific jobs that employees did, HR

Muhammad Baiquni and Ayu Aprilianti Lizar, Journal of Human Resources Management Research, DOI: $10.5171 / 2020.393044$ 
practices that kept the employee in the organization, and employee engagement also mediate the influence of job characteristics on organizational commitment. Therefore, the practice of HRs in respondents' companies more directly influences employees' organizational commitment. An HR practice that can support organizational commitment is offering training and rewards. Although industry conditions are sub-optimal, the company will always be in business and can offer rewards to employees. Not all HR practices can be used in all jobs-certain HR practices have been shown to work in only certain types of jobs (Lamba and Choudhary, 2013).

\section{Implications for Practice}

The results in the previous discussion indicate that the coal mining company requires strong strategic planning. To emphasize improvements in organizational commitment, the company can review job characteristics, employee engagement, and HR practices. However, job characteristics not only affect the organization's commitment but also employee engagement. The role of the HRs department in designing the strategies imposed within an organization can be based on these two factors. The characteristics of the existing work of the respondents, which requires dedication and significant skills, significantly affect the engagement of the employees in the respondent company. Therefore, if the company can improve job characteristics through increased autonomy or feedback, employee engagement and employee organizational commitment can also be strengthened.

To improve organizational commitment with HR practices, management can focus on improving training programs and give rewards to employees. During this time, the company-instead of responding simply by talking-can improve its response to problems by providing appropriate training because the work in the mining industry requires training and additional insights to support employees' efforts. Training that was previously based solely on employee demand can be improved again by offering general annual training that enhances employee skills. Then, profit sharing and job security for employees can also be implemented to give employees a bonus when the company's achievements exceed its targets. Regarding job security, employees can be given payroll certainty as well as an assured future career within the company.
In addition, job characteristics become one of the variables that affect the commitment of the organization either directly or mediated by other variables. Job characteristics that encourage employers to use a variety of skills when engaged in their assigned tasks can encourage employees to be more committed within the organization. Challenges given can be one way to increase employee commitment. Regarding the respondent company, employees are always expected to contribute more to the company. Job characteristics can be used in an approach to developing corporate strategy and can be supported by providing a variety of jobs to employees to avoid demotivating them. In addition, supervisors can provide feedback on their employees' performance given that the descriptive analysis indicated that feedback provided can be productive and supervisor support can better assist employees in understanding how they perform. The company can provide variations in work, job rotations, and feedback to increase employees' organizational commitment.

Employee engagement is also important to a company, has a direct influence on organizational commitment, and mediates other variables in this research. To improve organizational commitment through employee engagement, the company can implement training aimed at improving employee skills. This approach aims to support the characteristics of the existing work because the job characteristics factor is a variable that affects employee engagement. If the factors that affect employee engagement can be improved, employee engagement can contribute to increasing organizational commitments. The application of fixed working hours-overdue as an assessmentcan assist with the company's preliminary analysis to identify internal problems. Mentoring and coaching are needed to overcome employee problems on the job and with the organization, and are important to giving employees a way to contribute broadly to the organization and their work. Additionally, encouraging employees on their jobs through mentoring and coaching can increase employee enthusiasm and improve employee engagement.

\section{Limitations and Recommendations}

The results indicate that research on organizational commitment and employee engagement can be developed further to provide additional information for practitioners to develop 
an approach within the organization. This research has limitations also. The first limitation is the data collection-given that respondents are from a coal mining company, the data collection took time. The second limitation is response bias caused by the similar responses for all of the questions. Finally, a small sample size limits the results of this research, and the negative results may also have been caused by the sample size.

Based on current research, the recommendations for further studies are as follows. Further research can evaluate questionnaires with negative sentences to improve the results obtained. The use of translated sentences from the original questionnaire also needs to be considered to prevent differences in the understanding of the respondents. Using a larger research subject can broaden its overview. Future research can also adopt a qualitative approach to better understand and validate the information already obtained from the data and the results of the analysis. A qualitative approach is needed to confirm the results that may differ from those of other research because different respondents can produce different results. A more general sampling method, such as randomized sampling, can be used to generalize the results for broader purposes.

\section{Conclusion}

The research on organizational commitment can be expanded to cover additional industries. The implementation of a strategy to improve organizational commitment can be different for each industry. The first conclusion from this research is job characteristics, HR practices, and employee engagements have significant positive influences on organizational commitment. The second conclusion is employee engagement mediates the relationship between organizational commitment and job characteristics. The third conclusion is employee engagement is also influenced by job characteristics and HR practices.

\section{Reference}

- $\quad$ Akhtar, S., Ding, D. Z. and GE, G. L. (2008) 'Strategic hrm practices and their impact on company performance in chinese enterprises', Human Resource Management, 47(1), pp. 1532. doi: $10.1002 / \mathrm{hrm}$.

- Albdour, A. A. and Altarawneh, I. I. (2014) 'Employee engagement and organizational commitment: Evidence from Jordan', International Journal of Business, 19(02), pp.
192-212.

- Allen, N. J. and Meyer, J. P. (1990) 'The measurement and antecendents of affective, continuance and normative commitment to the organization', Journal of Occupational Psychology, pp. 1-18.

- Allen, N. J. and Meyer, J. P. (1996) 'Affective, continuance, and normative commitment to the organization: An examination of construct validity', Journal of vocational behavior, 49(3), pp. 252-76. doi: 10.1006/jvbe.1996.0043.

- Armstrong, M. (2014) Armstrong's handbook of human resource management practice, Human Resource Management. doi: 10.1007/s10551-011-1141-1.

- Arthur, J. (1994) 'Effects of human resource systems on manufacturing performance and turnover', Academy of Management journal, 37(3), pp. 670-687. doi: 10.2307/256705.

- Bakker, A. B. and Demerouti, E. (2008) 'Towards a model of work engagement', Career Development International, 13(3), pp. 209223. doi: $10.1108 / 13620430810870476$.

- Crook, T. R. et al. (2011) 'Does human capital matter? a meta-analysis of the relationship between human capital and firm performance', Journal of Applied Psychology, 96(3), pp. 443-456. doi: 10.1037/a0022147.

- DBS Group Research (2017) Masa Depan Sektor Batubara Indonesia - DBS Asian Insights IndonesiaDBS Asian Insights Indonesia. Available at: https://www.dbsinsights.com/id/energi-danlingkungan/masa-depan-sektor-batubaraindonesia (Accessed: 23 February 2018).

- Delery, J. E. and Doty, D. H. (1996) 'Modes of theorizing in strategic human resource management: Tests of universalistic , contingency , and configurational performance', Academy of Management Journal, 39(4), pp. 802-835.

- Dessler, G., Cole, N. D. and Sutherland, V. L. (2017) Human Resources Management, Human Resources Management in Perspective. doi: 10.4018/978-1-4666-1601-1.

- Fiorito, J. et al. (2007) 'Organizational commitment, human resource practices, and organizational characteristics', Journal of Managerial Issues, 19(2), pp. 186-207.

- $\quad$ Fornell, C. and Larcker, D. F. (1981) 'Evaluating structural equation models with unobservable variables and measurement error', Journal of Marketing Research, 18(1), p. 39. doi: $10.2307 / 3151312$.

- Gursoy, D., Maier, T. A. and Chi, C. G. (2008)

Muhammad Baiquni and Ayu Aprilianti Lizar, Journal of Human Resources Management Research, DOI: $10.5171 / 2020.393044$ 
'Generational differences: An examination of work values and generational gaps in the hospitality workforce', International Journal of Hospitality Management, 27(3), pp. 448-458. doi: 10.1016/j.ijhm.2007.11.002.

- Hackman, J. R. and Oldham, G. R. (1976) 'Motivation through the design of work: Test of a theory', Organizational Behavior and Human Performance, 16(2), pp. 250-279. doi: 10.1016/0030-5073(76)90016-7.

- Harter, J. K., Schmidt, F. L. and Hayes, T. L. (2002) 'Business-unit-level relationship between employee satisfaction, employee engagement, and business outcomes: A metaanalysis', Journal of Applied Psychology, 87(2), pp. 268-279. doi: 10.1037//00219010.87.2.268.

- Hofstede, G., Hofstede, G.J. and Minkov, M., 2005. Cultures and organizations: Software of the mind (Vol. 2). New York: Mcgraw-hill.

- Koch, M. J. and Mcgrath, R. G. (1996) 'Improving Labor Productivity: Human Resource Management Policies do Matter', Strategic Management Journal, 17(5), pp. 335354. doi: 10.1002/(sici)10970266(199605)17:5<335::aid-

smj814>3.0.co;2-r.

- Kulik, C. T., Oldham, G. R. and Hackman, J. R. (1987) 'Work design as an approach to person-environment fit', Journal of Vocational Behavior, 31(3), pp. 278-296. doi: 10.1016/0001-8791(87)90044-3.

- Lamba, S. and Choudhary, N. (2013) 'Impact of HRM practices on organizational commitment of employees', International Journal of Advancements in Research \& Technology, 2(4), pp. 407-423. doi: 10.7813/20754124.2014/6-5/B.3.

- $\quad$ Lee, S. M., Lee, D. and Kang, C.-Y. (2012) 'The impact of high-performance work systems in the health-care industry: employee reactions, service quality, customer satisfaction, and customer loyalty', The Service Industries Journal, 32(1), pp. 17-36. doi: 10.1080/02642069.2010.545397.

- $\quad$ Lee Whittington, J. and Galpin, T. J. (2010) 'The engagement factor: Building a highcommitment organization in a lowcommitment world', Journal of Business Strategy, 31(5), pp. 14-24. doi: 10.1108/02756661011076282.

- Macey, W. H. and Schneider, B. (2008) 'The meaning of employee engagement', Industrial and Organizational Psychology, 1(01), pp. 330. doi: 10.1111/j.1754-9434.2007.0002.x.
- Meyer, J. P. et al. (2002) 'Affective, continuance, and normative commitment to the organization: A meta-analysis of antecedents, correlates, and consequences', Journal of Vocational Behavior, 61(1), pp. 2052. doi: 10.1006/jvbe.2001.1842.

- Meyer, J. P. and Smith, C. A. (2000) 'HRM practices and organizational commitment: Test of a mediation model', Canadian Journal of Administrative Sciences / Revue Canadienne des Sciences de l'Administration, 17(4), pp. 319-331. doi: 10.1111/j.19364490.2000.tb00231.x.

- Mowday, R. T., Porter, L. W. and Steers, R. M. (1983) Employee-Organization linkages: The psychology of commitment, absenteeism, and turnover, American Journal of Socioty. doi: $10.2307 / 2068333$.

- Ogilvie, J. R. (1986) 'The tole of human resource management practices in predicting organizational commitment', Group \& Organization Management, 11(4), pp. 335359. doi: $10.1177 / 0364108286114003$.

- Paul, A. K. and Anantharaman, R. N. (2004) 'Influence of HRM practices on organizational commitment: A study among software professionals in India', Human Resource Development Quarterly, 15(1), pp. 77-88. doi: 10.1002/hrdq.1088.

- Pfeffer, J. (1994) 'Competitive advantage through people', Calfornia Management Review, 36(2), pp. 9-28. doi: 10.1016/01664972(95)90005-5.

- Rai, A. et al. (2017) 'Influence of job characteristics on engagement: does support at work act as moderator?', International Journal of Sociology and Social Policy, 37(1/2), pp. 86-105. doi: 10.1108/IJSSP-10-20150106.

- Robinson, D., Perryman, S. and Hayday, S. (2004) 'The drivers of employee engagement', North, 408, pp. 12-15. doi: IES Report No. 408.

- Saks, A. M. (2006) 'Antecedents and consequences of employee engagement', Journal of Managerial Psychology, 21(7), pp. 600-619. doi: 10.1108/02683940610690169.

- Schaufeli, W. B., Bakker, A. B. and Salanova, M. (2006) 'The measurement of work engagement with a short questionnaire: A cross-national study', Educational and Psychological Measurement, 66(4), pp. 701716. doi: $10.1177 / 0013164405282471$.

- Schaufeli, W. B. and Salanova, M. (2007) 'Work engagement: An emerging psychological concept and its implications for organizations',

Muhammad Baiquni and Ayu Aprilianti Lizar, Journal of Human Resources Management Research, DOI: $10.5171 / 2020.393044$ 
in Managing Social and Ethical Issues in Organizations, pp. 135-177. doi: 10.1080/02678370802393649.

- Tiwari, P. and Saxena, K. (2012a) 'Human resource management practices: A comprehensive review', Pakistan Business Review, 9(2), pp. 669-705.

- Tiwari, P. and Saxena, K. (2012b) 'Human Resource Management Practices: A comprehensive Review', Pakistan Business Review, 9(2)(January 2012), pp. 669-705.

- Ulrich, D. (1997a) 'HR of the future: Conclusions and observations', Human Resource Management, 36(1), pp. 175-179. doi: $\quad 10.1002 /(S I C I) 1099-$ 050X(199721)36:1<175::AIDHRM28>3.0.C0;2-9.

- Ulrich, D. (1997b) 'Measuring human resources: An overview of practice and a prescription for results', Human Resource Management, pp. 303-320. doi: 10.1002/(SICI)1099-

050X(199723)36:3<303::AIDHRM3>3.0.CO;2-\#.

- Wiener, Y. (1982) 'Commitment in organizations: A normative view', The Academy of Management Review, 7(3), p. 418. doi: $10.2307 / 257334$.

- Wood, S. and De Menezes, L. (1998) 'High commitment management in the U.K.: Evidence from the workplace industrial relations survey, and employers' manpower and skills practices survey', Human Relations, pp. 485-515. doi: 10.1177/001872679805100403. 